再建用臓器の副病変をもった食道癌の外科治療

\begin{tabular}{lcc}
\multicolumn{5}{c}{ 虎の門病院消化器外科 } \\
小野 由雅 鶴丸 昌彦 渡辺 五朗 \\
秋山 洋
\end{tabular}

\title{
SURGICAL TREATMENT OF ESOPHAGEAL CANCER ASSOCIATED WITH THE ACCESSORY LESION IN AN ESOPHAGEAL SUBSTITUTE
}

\author{
Yoshimasa ONO, Akihiko THURUMARU, Goro WATANABE \\ and Hiroshi AKIYAMA
}

Department of Surgery Toranomon Hospital

索引用語：食道癌, 胃潰暍

はじめに

当科において食道癌切除術における再建術式は，下 咽頭頝部食道癌で胸部食道を抜去する場合は, 全胃を 後綎隔経路に挙上し咽頭胃吻合を行い'，胸腹部食道 癌の場合は，胸骨後経路に胃上部切除後の残胃を挙上 し頝部食道胃吻合を標準術式としている2)。いずれの 場合にも胃を再建用葴器として用いている。この胃に 潰瘍や癌が合併した場合や胃切除術後症例の場合, さ らに良悪性判定困難な副病変が合併した場合に，当科 で行われた切除再建術式について検討を加え, 各副病 変に対する私どもが行っている方法の原則について報 告する。

\section{検索対象}

虎の門病院消化器外科に打いて，1973年 1 月から 1983 年 8 月までの約 10 年間に入院した 624 例の食道癌 症例のらち, 再建用臓器としての胃に副病変をみとめ たのは113例 (18.1\%)であった。このうち切除再建ま たはバイパス術を行った56例を対象とした

\section{成綨および考寒}

再建用臟器としての胃に副病変をみとめた 113 例の 内訳は, 胃潰瘍(湶痕も含め)が最も多く 35 例(5.6\%), 同時性重複癌となる胃癌が33例 (5.3\%), 胃切除術後 症例がこれらについで28例 (4.5\%)であった（表 1 ).

※第23回日消外会総会シンポII：他臟器の機能障害ま たは副病变をもった食道癌の外科的治療 別刷請求先：小野 由雅

厂105 港区虎の門 $2-2-2$ 虎の門病院消化器外 科
表 1 食道癌症例の胃(十二指腸)にみられる副病変

\begin{tabular}{|c|c|c|c|}
\hline 胃（十二指腸）病変 & 症例数 & & 合併頻度 \\
\hline 潰瘍(湃痕を含む) & 35例 & $35 / 624$ 例 & $5.6 \%$ \\
\hline 十二指 腸 潰 瘍(揤痕を含む) & 9例 & $9 / 624$ 例 & $1.4 \%$ \\
\hline 胃・十二指腸溃瘍 & 1例 & $1 / 624$ 例 & $0.16 \%$ \\
\hline 癌(同時性重䙓癌 & & & \\
\hline $\begin{array}{cc}\text { 早期癌 } & 21 \text { 例 } \\
\text { 進行癌 } 12 \text { 12例 }\end{array}$ & 33例 & $33 / 624$ 例 & $5.3 \%$ \\
\hline 良性悪性判定困難な胃病変 & 7例 & $7 / 624$ 例 & $1.1 \%$ \\
\hline 胃切除 術 後 & 28例 & 28/624例 & $4.5 \%$ \\
\hline 計 & 113例 & $113 / 624$ 例 & $18.1 \%$ \\
\hline
\end{tabular}

1. 胃または十二指腸潰瘍 (瘦痕子含め) 合併症例に ついて (表 2)

胃潰瘍または十二指腸潰瘍を有する45例のうち43例 に対して食道再建術または食道バイパス術を行った。 漬瘍を切除側に含めて胃上部切除を行い残胃を举上し 再建したもの14例，胃全剔を行い結腸を举上し再建を 行ったもの10例であった。 十二指腸潰煬で胃全剔を 行ったものが 1 例あるが, この症例は $\mathrm{Ea}$ 症例で肛門 側浸潤が噴門部に広範に及んでいたために胃全剔を 行った，疫痕といえども胃潰瘍は原則として切除する 方針であるが，それは食道癌による高度の狭窄のため 術前検索が十分行兄ず，そのまま胃を再建用臓器とし て用いて再建した 1 例に，術後潰瘍からの大出血を経 験したためで，この原則にもとづく再建を行い，以後 は全くこうした合併症は経験していない，胃漬場の存 在部位は体部11例，胃角部19例，前庭部 4 例であった 


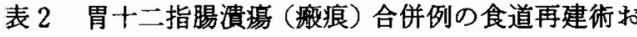
よびパイパス術式

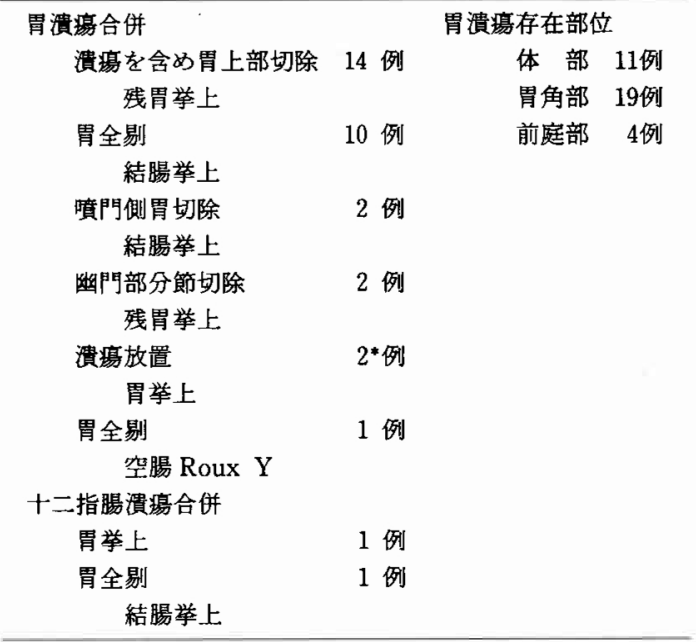

1973. $1 \sim 1983.8$

・術後出血 1 例

（表 2 ），胃角部付近までの胃漬瘍の場合，通常挙上胃 作製の 3 つの原則 ${ }^{3)}$. 1）胃上部リソパ節群 No. 1, 2,3 の必要かつ十分な切除，2）胃壁の vascalar net work の温存, 3） highest point の選択に加之て, 術中胃切開 を行い潰場の存在部位を確認し，切除側にこれを含め る形で切離線を決定した(図 1)。しかしながらこの方 法で胃の血流が温存できないと判定され，胃全剔を行 い結腸で再建した症例が10例ある。胃潰瘍が前庭部ま たは前庭部に近い胃角部に存在する症例では，右胃動 脈と右胃大網動脈を温存するように潰瘍を含めた前庭

因 1 胃漬瘍合併例に於ける胃切離線の決定

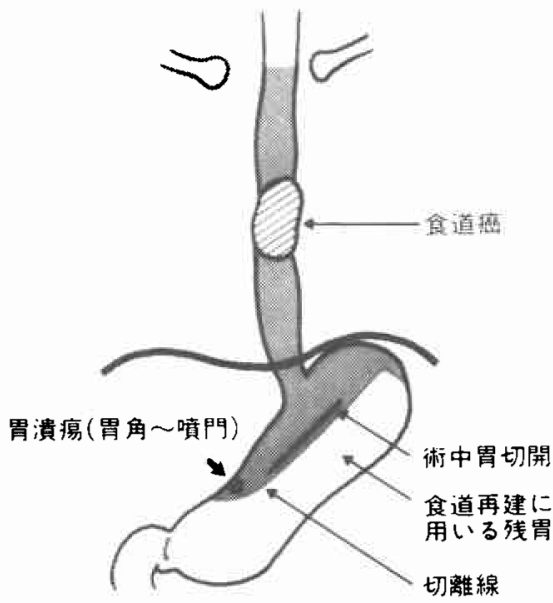

部の分節切除を行い残胃を挙上する. 頝部において頝 部食道胃吻合を行い，肛門側は胃空腸吻合を RouxenY 法または Billoth II 法にて行った(図 2, 写真 1).

2. 同時性食道胃重複癌症例について（表 3）

阿保出らの報告では食道の同時性重複癌症例251例 の5ち186例 (76.5\%) が胃で最も多いが，当科におい ては，同期間中の624例中33例（5.3\%）に同時性食道 胃重複癌がみとめられた。これらについて術前診断に て胃癌の存在が確認しえた症例は28例(85\%), 口側病 変の食道癌による狭窄のため存在が確認されなかった 症例は 5 例（15\%）であった。両癌を一期的に切除し

図 2 胃潰瘍合併例に対する幽門部分節切除術

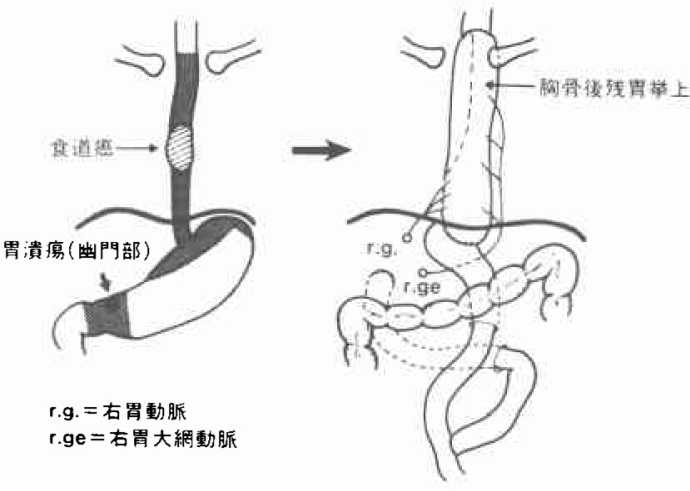

写真 1

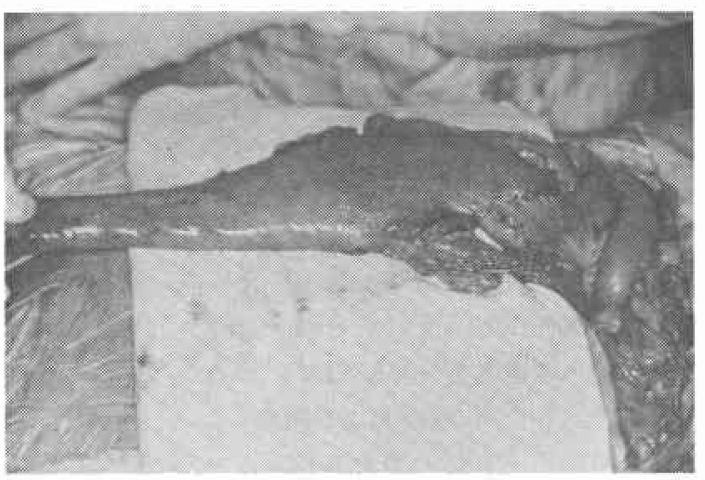

表 3 胃・食道同時性重複癌 33例

\begin{tabular}{|c|c|c|c|c|}
\hline \multirow{2}{*}{\multicolumn{2}{|c|}{$\begin{array}{l}\text { く術前診断〉 } \\
\text { 術前診断されたもの }\end{array}$}} & & & \\
\hline & & 進行 & 12 & \\
\hline $\mathrm{X}$ 線 & & & 癌 & 21 例 \\
\hline 内視鏡 & 23例 & 部位 & 早期癌 & 進行癌 \\
\hline $\mathrm{X}$ 線のみ & 5例 & $\mathrm{C}$ & 2 例 & 5 例 \\
\hline 内視鏡のみ & 0例 & $\mathbf{M}$ & 6 例 & 3 例 \\
\hline 衍前診断されないもの & 5 例 & A & 1 例 & 16例 \\
\hline
\end{tabular}


表 4 良・悪性判定困難な胃病変を合併する食道癌症例

\begin{tabular}{|c|c|c|c|c|c|c|c|c|c|}
\hline 症例 & 年齢 & 性 & 胃 病 変 & $\begin{array}{l}\text { 柶前生検 } \\
\text { 診断 }\end{array}$ & 食道癌 & 式 & 術後胃病変組織診断 & 合併病変 & 術後合併症 \\
\hline 1. & 70 & $\mathbf{M}$ & $\begin{array}{l}1 \times 1(\mathrm{~mm}) \\
\text { 胃体下部後壁 }\end{array}$ & 施行できず & Ei $A_{0} N_{2(-)} M_{0} \mathrm{Pl}_{0}$ & 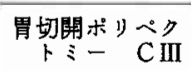 & Group 1 & \begin{tabular}{l} 
結腸多発 \\
\multirow{2}{*}{ プー }
\end{tabular} & 㹟 窄 \\
\hline 2. & 55 & $\mathbf{M}$ & $\begin{array}{l}11 \times 5 \\
\text { 胃体下部前壁 }\end{array}$ & 施行できず & $\operatorname{lm} \mathrm{A}_{2} \mathrm{~N}_{2(+)} \mathrm{M}_{0} \mathrm{Pl}_{0}$ & 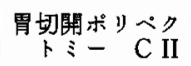 & Group 3 & 結腸 & 肺 资 \\
\hline 3. & 80 & $\mathbf{M}$ & $\begin{array}{l}4 \times 5 \\
\text { 前庭部 }\end{array}$ & 施行できず & $\operatorname{lm} A_{1} N_{2(-)} M_{0} P_{0}$ & 放 置 C III & 不 明 & $(-)$ & 肺 炎 \\
\hline 4. & 66 & $\mathbf{M}$ & $\begin{array}{l}5 \times 5 \\
\text { 胃体下部後壁 }\end{array}$ & Group 3 & lu $\quad \mathrm{A}_{3} \mathrm{~N}_{3(+)} \mathrm{M}_{0} \mathrm{Pl}_{0}$ & 胃切開ボリ & Group 3 & $(-)$ & $\underset{\text { Ieakage }}{\operatorname{minor}}$ \\
\hline 5. & 58 & $\mathbf{M}$ & $\begin{array}{l}10 \times 5 \\
\text { 弯隆部 }\end{array}$ & 施行できず & $\mathrm{Ph} \quad \mathrm{A}_{3} \mathrm{~N}_{2(+)} \mathrm{M}_{0} \mathrm{Pl}_{0}$ & 局所切除 C I & $\begin{array}{l}\text { leiomyosarcoma(low } \\
\text { grade malignancy) }\end{array}$ & $(-)$ & $(-)$ \\
\hline 6. & 71 & $\mathrm{~F}$ & $\frac{20 \times 12}{\text { 前庭部 }}$ & 施行できず & Ei $\quad A_{2} N_{4(+)} M_{0} P_{0}$ & 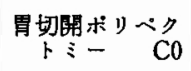 & cancer in adenoma & $(-)$ & 肺 炎 \\
\hline 7 . & 57 & $\mathbf{M}$ & $\frac{15 \times 10}{\text { 前庭部 }}$ & Group 2 2 & $\operatorname{lm} \mathrm{A}_{2} \mathrm{~N}_{2(+)} \mathrm{M}_{0} \mathrm{Pl}_{0}$ & 胃全剔 C III & II a subtype & 胃壁内転移 & $(-)$ \\
\hline
\end{tabular}

1973. $1 \sim 1983.8$

因 3 胃切除後症例の再建術式

B-I 法

$-1983.9$

えた症例は17例 (52\%) であった。残りの16例 (48\%) は食道癌の進行が高度なため非切除になった，重複癌 の昜合には理論的には両癌に対してできうるかぎり根 治性を得る切除を行うべきである．しかしながら食道 癌の進行度とその切除の根治性と, 合併切除について の安全性を十分考虑した上で，バランスのとれた切除 術式を選択している。切除例の中に, 術中はじめて胃 の早期癌の存在が判明したが, 食道癌の進行度および 患者の心腎招よび肺機能低下による poor riskのた め，あえて結腸による再建に変更せずに胃病変につき OW (十)のままで胃を用いて再建し, 術後照射を加 党, 術後厳重に follow up てている症例がある.

3. 胃切除術後症例について

胃または十二指腸漬場に対してすでに胃切除術が行 われている症例24例, 胃癌に対して胃切除術が行われ ている症例が 4 例であった。前回胃手術が癌の場合で
はNo１，3，7，9がすでに郭清されているはずである が，食道癌切除の際には残胃全剔を行い，特に転移傾 向の強い No. 1, 2, 3, 7, 8, 9 の完全な郭清を期さねば ならない，胃切除の際の再建が， Billoth-I 法か，Billoth-II 法3)で行われているかにより食道再建は, 図 3 のごとく行った. Billoth-I 法の場合では, 結腸挙上し その肛門側を Billoth-II 法に準じて空腸と吻合したも の 3 例, 残胃に端側吻合したもの 2 例, 十二指腸と端々 吻合したもの 2 例であった。一方 Billoth II 法の場合 は Roux-enY 法 2 例, 残胃々の吻合 2 例, Billoth-II 法 に準じて空腸を吻合したもの4例であった。

4. 良・悪性判定困難な胃病変合併症例について

良・悪性判定困難症例は 7 例 (1.1\%) にみとめられ た.胃癌および胃潰瑒の合併に注意をはらうことより, こうした症例る增加すると考えられる。症例 5 は leiomyosarcoma (low grade malignancy) の疑いと の診断であり，全層の胃の部分切除を行った。carcinoma in adenoma の症例 6 の場合は, 術中胃切開を 招き局在之病変の性格を肉眼的に判定し, 術中 polypectomyを行った。

術前組織診断状が得られない症例が 7 例中 5 例と多 いため，潰瘍と同様に術中切開を行い，病変の局在と 肉眼所見より，必要あれば迅速組織診断を行う必要が ある. Polypectomy などの局所切除を行い再建に胃を 用いたもの 5 例，胃壁内転移巣が合併するため，胃全 剔を行い結腸で再建したもの 1 例, 残りの 1 例は 80 歳 と高龄のため, 食道癌の進展度を考虑し, 胃病変は $4 \times$ $5 \mathrm{~mm}$ の小さな隆起性病変であり,はっきり悪性所見が えられないため, 胃病变は処置をせずそのまま再建に 
用いた。

$$
\text { まとめ }
$$

1. 再建用萮器としての胃に副病変をみとめた113例 は, 胃潰瘍 (疫痕子含め) 35例 (31\%) 胃癌33例 (29\%) 胃切除衍後症例 28 例 (25\%), 良·悪性判定困難な胃病 変 7 例 $(5.4 \%)$ であった。

2. 胃潰瘍合併の場合, 原則的に㗪痕を含め潰漡は切 除し, 胃を再建に用いるが, 残胃が再建用臟器として 使用困難な場合には結腸を用いる。この原則により基 つき29例に対して再建術を行った，術後举上胃よりの 出血はみとめなかった。

3. 食道胃の同時性重複癌に対しては, 食道癌の進展 度と症例のリスクを考虑し，胃癌の切除術式を考虑す
べきである。

4. 良・悪性判定困難な胃病变に対しては, 術中胃切 開を行い, 術中肉眼所見や術中迅速組織所見を行って 切除方法につき検討すべきである.

$$
\text { 女献 }
$$

1）鶴丸昌彦, 秋山 洋: 頝部食道下咽頭漓根治術. 消 外 $3: 1906-1917,1980$

2) Akiyama $\mathrm{H}$ : Surgery for carcinoma of the esophagus. Curr Prob Surg $17: 53-120,1980$

3）秋山 洋, 宮荳 光, 鶴丸昌彦: 食道再建用胃の作 製规則. 臨外 $34: 695-702,1979$

4）阿保七三郎, 三浦秀男, 工藤 保仿：日本におけ る食道と他醎器の重袮癌について。 日消外会誌 $13: 377-381,1980$ 